\title{
THE END OF DIVERSITY?
}


A volume in the series

Cornell Studies in Political Economy Edited by Peter J. Katzenstein A full list of titles in the series appears at the end of the book. 


\section{THE END OF DIVERSITY? \\ Prospects for German and Japanese Capitalism}

EDITED BY

\section{Kozo Yamamura}

and

Wolfgang Streeck

Cornell University Press

ITHACA AND LONDON 


\section{Copyright $\odot 2003$ by Cornell University}

All rights reserved. Except for brief quotations in a review, this book, or parts thereof, must not be reproduced in any form without permission in writing from the publisher. For information, address Cornell University Press, Sage House, 512 East State Street, Ithaca, New York 14850.

First published 2003 by Cornell University Press

First printing, Cornell Paperbacks, 2003

Printed in the United States of America

Library of Congress Cataloging-in-Publication Data

The end of diversity? : prospects for German and Japanese capitalism / edited by Kozo Yamamura and Wolfgang Streeck.

p. cm.-(Cornell studies in political economy)

Includes bibliographical references and index.

ISBN 0-80I 4-4088-2 (cloth : alk. paper)-ISBN 0-8014-8820-6 (pbk. : alk. paper)

1. Capitalism-Germany. 2. Germany-Economic policy.

3. Capitalism-Japan. 4. Japan-Economic policy. I. Yamamura, Kåozåo. II. Streeck, Wolfgang, 1946- III. Series.

HC286 .8 .E49 2003

$330.943-\mathrm{d} c 21$

Cornell University Press strives to use environmentally responsible suppliers and materials to the fullest extent possible in the publishing of its books. Such materials include vegetable-based, low-VOC inks and acid-free papers that are recycled, totally chlorine-free, or partly composed of nonwood fibers. For further information, visit our website at www.cornellpress.cornell.edu.

$\begin{array}{lllllllllll}\text { Cloth printing } \quad 10 & 9 & 8 & 7 & 6 & 5 & 4 & 3 & 2 & 1\end{array}$

Paperback printing $\quad \begin{array}{lllllllllll}10 & 9 & 8 & 7 & 6 & 5 & 4 & 3 & 2 & 1\end{array}$

